\title{
Value of alpha-fetoprotein in hepatocellular carcinoma
}

\author{
Wei-Chen Lee \\ Division of Liver and Transplantation Surgery, Department of General Surgery, Chang-Gung Memorial Hospital, Chang-Gung University College \\ of Medicine, Taoyuan \\ Correspondence to: Wei-Chen Lee, MD. Division of Liver and Transplantation Surgery, Department of General Surgery, Chang-Gung Memorial \\ Hospital, 5, Fu-Hsing Street, Kwei-Shan, Taoyuan. Email: weichen@cgmh.org.tw. \\ Comment on: Chan MY, She WH, Dai WC, et al. Prognostic value of preoperative alpha-fetoprotein (AFP) level in patients receiving curative \\ hepatectomy- an analysis of 1,182 patients in Hong Kong. Transl Gastroenterol Hepatol 2019;4:52.
}

Received: 03 December 2019; Accepted: 23 December 2019; Published: 25 October 2021.

doi: $10.21037 /$ tgh.2019.12.19

View this article at: http://dx.doi.org/10.21037/tgh.2019.12.19

In July issue of this Journal, Chan et al. published a paper focusing on prognostic value of pre-operative alphafetoprotein (AFP) level in the patients receiving hepatectomy for hepatocellular carcinoma (HCC) (1). They collected 1,182 patients who had curative hepatectomy for HCC. The patients were divided into 3 groups: AFP $<20,20-400$ and $>400 \mathrm{ng} / \mathrm{mL}$. The patients with AFP $>400 \mathrm{ng} / \mathrm{mL}$ were younger than the patients with AFP $<20$ or 20 $400 \mathrm{ng} / \mathrm{mL}$. Because they were young, the patients with AFP $>400 \mathrm{ng} / \mathrm{mL}$ have less incidence of comorbid diseases. The patients with AFP $>400 \mathrm{ng} / \mathrm{mL}$ had larger tumors and up to $65.9 \%$ of the patients had vascular invasion. The 5 -year overall and disease-free survival were significantly lower than the patients with AFP $<20 \mathrm{ng} / \mathrm{mL}$ and the patients with AFP between 20 to $400 \mathrm{ng} / \mathrm{mL}$. Dr. Chan also used receiver operating characteristic curve to search the optimal cut off value of AFP for disease-free and overall survival. They found that the survival rate was compatible to one stage up for disease-free survival if AFP was $>9,000 \mathrm{ng} / \mathrm{mL}$ and one stage up for overall survival if AFP was $>14,000 \mathrm{ng} / \mathrm{mL}$. Finally, they claimed that pre-operative AFP level was a significantly prognostic factor to predict survival. High level of AFP >9,000 and >14,000 ng/mL warrant an up stage of the diseases for disease-free and overall survival, respectively.

AFP is produced from embryonic endoderm tissue cells during fetus. After birth, production of AFP is reduced to a very low level. In 1968, Dr. Alpert et al. found that AFP was produced in $50 \%$ of HCC patients (2). Since then, AFP becomes a tumor marker of hepatocellular carcinoma (HCC). Currently, AFP is applied as one of the parameters to screen HCC in chronic hepatitis patients and is also applied as one of the diagnostic criteria of HCC (3). When AFP is more than $400 \mathrm{ng} / \mathrm{mL}$, HCC is diagnosed excluding pregnancy (4). Clinically, AFP will appear in two-third of HCC patients.

Early stage HCC can be treated by liver resection, liver transplantation and local ablation (5). Liver resection is still the most popular curative treatment for early stage HCC in Asia because liver transplantation needs a liver graft and liver grafts are always lack. However, HCC is easy to recur even the tumor is resected completely. The reported 5 -year recurrent rate is around $50 \%$ which compromises the 5 -year tumor-free and overall survival $(6,7)$. The risk factors are analyzed by many studies and the results show that liver cirrhosis, tumor size, tumor number, AFP level, blood loss, blood transfusion, resection margin, encapsulation of tumor, micro-/macro-vascular invasion, stellate tumors, and tumor histological differentiation all are the prognostic factors for liver resection $(6,8,9)$. All these factors can be classified into three categories: liver inflammation, surgical technique and tumor pathology. That is the prognosis of HCC is already determined preoperatively by liver biology and tumor behavior. Until now, several biomarkers such as Des-c-carboxy prothrombin (DCP) or Lens culinaris agglutinin reactive AFP (AFP-L3) are suggested to be biomarkers for HCC $(10,11)$, however, AFP is still the most popular biomarker for HCC although AFP is elevated in only two-third of HCC patients. AFP has been studied to correlate to tumor biology. Dr. Ma et al. divided their patients into 3 groups according to AFP $\leq 20,20-400$ and $\geq 400 \mathrm{ng} / \mathrm{mL}$ which was similar to Dr. Chan's study and they found that tumors in the patients with AFP $\leq 20 \mathrm{ng} / \mathrm{mL}$ 
had higher cell differentiation, lower vascular invasion and lower 2-year recurrent rate than other groups (12). Dr. Peng et al. reported that the patients with AFP $\geq 200 \mathrm{ng} / \mathrm{mL}$ were associated with p53 mutation and early tumor recurrence (13). Dr. Wu et al. also mentioned that hazard ratio of early tumor recurrence after liver resection was 3.891 when AFP was more than $20 \mathrm{ng} / \mathrm{mL}$ (14). Therefore, high level of AFP is recognized as aggressive behavior of HCC and is associated with microvascular invasion, poor cellular differentiation, and poor prognosis.

When liver resection is performed to remove the tumor/ tumors, a safe margin should be created to guarantee complete removal of the tumors. How wide of resection margin is adequate is still controversial. Dr. Zhou et al. have reported that $21.9 \%$ of the surgical specimens had micrometastasis and the distance of micro-metastasis to resection margin was up to $6 \mathrm{~mm}$ for the HCC without macrovascular invasion (15). If the tumors were associated with macro-vascular invasion, the distance of micro-metastasis to resection margin would be up to $19 \mathrm{~mm}$. In our previous study, we found that the width of resection margin could be determined by pre-operative levels of AFP (16). Tumorfree margin is enough for the tumors with normal level of AFP, the width of resection margin should extend to $\geq$ $5 \mathrm{~mm}$ if AFP is between 15 and $200 \mathrm{ng} / \mathrm{mL}$, and the width of resection margin should extend to $\geq 10 \mathrm{~mm}$ for the patients with AFP over $200 \mathrm{ng} / \mathrm{mL}$. Taking together, production of AFP is an aggressive behavior of HCC and the width of resection margin should be extended for the HCC with high AFP levels.

Liver transplantation is another curative treatment for early stage HCC if the tumors are within Milan criteria (17). Liver transplantation is the best treatment for cirrhotic liver with HCC because it removes diseased liver and HCC simultaneously. However, even the diseased liver is completely removed and a new liver is implanted, HCC still recurs in around $10 \%$ of the patients. If the indication of liver transplantation is extended, the survival rate will be compromised by a higher tumor recurrent rate (18). To our knowledge, microvascular invasion is the major factor of tumor recurrence in liver transplantation. Dr. Amado et al. have mentioned that the actual value of AFP was associated with poor differentiation of tumor cells and microvascular invasion which increased post-transplant HCC recurrence and reduced overall survival (19). Dr. Hakeem et al. reviewed 12,159 patients with liver transplantation for HCC and they found that pre-operative AFP $>1,000 \mathrm{ng} / \mathrm{mL}$ was associated with poor outcomes (20). AFP $>1,000 \mathrm{ng} / \mathrm{mL}$ is recognized as a risk factor for liver transplantation and liver transplantation is not recommended if HCC is with AFP $>1,000 \mathrm{ng} / \mathrm{mL}$. Since liver transplantation needs liver graft, no matter deceased or living donor liver grafts, the expectation of liver transplantation for HCC is to cure the malignancy. Currently, criteria such as Milan and UCSF (21), only tumor size and tumor number are included. To prevent tumor recurrence after transplantation, the criteria must beyond tumor size and tumor number and tumor biology is suggested to be included in the criteria of liver transplantation. The serum level of AFP reflects the aggressive biology of the tumors and may put into the criteria for liver transplantation.

What is the biological effect of AFP in immunity is not very clear. In a review article, Dr. Wang et al. collected the information that when exogenous AFP was added into culture medium of HCC cells in laboratory study, proliferation of HCC cells would be promoted and resisted to apoptosis (22). When AFP was added into DC culture, caspase and P38-MARK would be upgraded to induce apoptosis and keep DC in immature status which impairs immune function of natural-killer cells and T-cells. Therefore, AFP is not only the surrogate of tumor aggressiveness, but also help HCC to escape from antitumor immunity.

AFP is applied as a tumor biomarker for HCC for several decades although AFP is elevated in only two-third of HCC patients. Currently, AFP is not just a biomarker, but also a risk factor of tumor recurrence for liver resection and liver transplantation. In Dr. Chan's study, the HCC stage will be upgraded if AFP is $\geq 9,000 \mathrm{ng} / \mathrm{mL}$ for disease-free and $\geq 14,000 \mathrm{ng} / \mathrm{mL}$ for overall survival. All these clinical findings support the clinical value of AFP. But, how are HCC cells transformed to produce AFP is still not clear. The detail role of AFP in HCC still needs further studies to explore. The future studies will include to determine the vascular invasion property of AFP-producing HCC, metabolic pathway of AFP-producing HCC, hepatitis B DNA insertion of AFP-producing HCC, molecular expression of AFP-producing HCC, etc.

\section{Acknowledgments}

Funding: None.

\section{Footnote}

Provenance and Peer Review: This is an invited article 
commissioned by the Editorial Office, Translational Gastroenterology and Hepatology. The article did not undergo external peer review.

Conflicts of Interest: The author has completed the ICMJE uniform disclosure form (available at http://dx.doi. org/10.21037/tgh.2019.12.19). The author has no conflicts of interest to declare.

Ethical Statement: The author is accountable for all aspects of the work in ensuring that questions related to the accuracy or integrity of any part of the work are appropriately investigated and resolved.

Open Access Statement: This is an Open Access article distributed in accordance with the Creative Commons Attribution-NonCommercial-NoDerivs 4.0 International License (CC BY-NC-ND 4.0), which permits the noncommercial replication and distribution of the article with the strict proviso that no changes or edits are made and the original work is properly cited (including links to both the formal publication through the relevant DOI and the license). See: https://creativecommons.org/licenses/by-nc-nd/4.0/.

\section{References}

1. Chan MY, She WH, Dai WC, et al. Prognostic value of preoperative alpha-fetoprotein (AFP) level in patients receiving curative hepatectomy- an analysis of 1,182 patients in Hong Kong. Transl Gastroenterol Hepatol 2019;4:52.

2. Alpert ME, Uriel J, de Nechaud B. Alpha-1 fetoglobulin in the diagnosis of human hepatoma. $\mathrm{N}$ Engl J Med 1968;278:984-6.

3. Tinkle CL, Haas-Kogan D. Hepatocellular carcinoma: natural history, current management, and emerging tools. Biologics 2012;6:207-19.

4. Poon D, Anderson BO, Chen LT, et al. Management of hepatocellular carcinoma in Asia: consensus statement from the Asian Oncology Summit 2009. Lancet Oncol 2009;10:1111-8.

5. Forner A, Reig M, Bruix J. Hepatocellular carcinoma. Lancet 2018;391:1301-14.

6. Lee WC, Lee CF, Cheng CH, et al. Outcomes of liver resection for hepatocellular carcinoma in liver transplantation era. Eur J Surg Oncol 2015;41:1144-52.

7. Shrager B, Jibara G, Schwartz M, et al. Resection of Hepatocellular Carcinoma Without Cirrhosis. Ann Surg
2012;255:1135-43.

8. Lee WC, Jeng LB, Chen MF. estimation for prognosis after hepatectomy for hepatocellular carcinoma. Br J Surg 2002;89:311-6.

9. Nathan H, Schulick RD, Choti MA, et al. Predictors of survival after resection of early hepatocellular carcinoma. Ann Surg 2009;249:799-805.

10. Malaguarnera G, Giordano M, Paladina I, et al. Serum markers of hepatocellular carcinoma. Dig Dis Sci 2010;55:2744-55.

11. Singhal A, Jayaraman M, Dhanasekaran DN, et al. Molecular and serum markers in hepatocellular carcinoma: predictive tools for prognosis and recurrence. Crit Rev Oncol Hematol 2012;82:116-40.

12. Ma WJ, Wang HY, Teng LS. Correlation analysis of preoperative serum alpha-fetoprotein (AFP) level and prognosis of hepatocellular carcinoma (HCC) after hepatectomy. World J Surg Oncol 2013;11:212.

13. Peng SY, Chen WJ, Lai PL, et al. High alpha-fetoprotein level correlates with high stage, early recurrence and poor prognosis of hepatocellular carcinoma: significance of hepatitis virus infection, age, $\mathrm{p} 53$ and beta-catenin mutations. Int J Cancer 2004;112:44-50.

14. Wu JC, Huang YH, Chau GY, et al. Risk factors for early and late recurrence in hepatitis B-related hepatocellular carcinoma. J Hepatol 2009;51:890-7.

15. Zhou XP, Quan ZW, Cong WM, et al. Micrometastasis in surrounding liver and the minimal length of resection margin of primary liver cancer. World J Gastroenterol 2007; 13:4498-503.

16. Lee JC, Cheng CH, Wang YC, et al. Clinical relevance of alpha-fetoprotein in determining resection margin for hepatocellular carcinoma. Medicine (Baltimore) 2019;98:e14827.

17. Mazzaferro V, Regalia E, Doci R, et al. Liver transplantation for the treatment of small hepatocellular carcinomas in patients with cirrhosis. N Engl J Med 1996;334:693-9.

18. Yao FY. Liver transplantation for hepatocellular carcinoma: beyond the Milan criteria. Am J Transplant 2008;8:1982-9.

19. Amado V, Rodriguez-Peralvarez M, Ferrin G, et al. Selecting patients with hepatocellular carcinoma for liver transplantation: incorporating tumor biology criteria. J Hepatocell Carcinoma 2019;6:1-10.

20. Hakeem AR, Young RS, Marangoni G, et al. Systematic review: the prognostic role of alpha-fetoprotein following liver transplantation for hepatocellular carcinoma. Aliment Pharmacol Ther 2012;35:987-99. 
21. Yao FY, Ferrell L, Bass NM, et al. Liver transplantation for hepatocellular carcinoma: expansion of the tumor size limits does not adversely impact survival. Hepatology 2001;33:1394-403.

doi: $10.21037 / \operatorname{tgh} .2019 .12 .19$

Cite this article as: Lee WC. Value of alpha-fetoprotein in hepatocellular carcinoma. Transl Gastroenterol Hepatol 2021;6:52.
22. Wang X, Wang Q. Alpha-Fetoprotein and Hepatocellular Carcinoma Immunity. Can J Gastroenterol Hepatol 2018;2018:9049252. 